\title{
Do Democratic Institutions Reduce Human Rights Violations or Just Prevent More Violations than Current Levels? An Exogenous Explanation of Human Rights Improvements in Democracies
}

\author{
Youngsoo Yu
}

\begin{abstract}
This article argues that human rights improvements are hard to achieve even in democracies because elites and citizens may not want to sacrifice other policy goals for human rights reforms even though both elites and citizens are believed to prefer better human rights protections. Improving human rights is a costly job that requires capacity to deter or reconcile with opposition against reforms, rationales and incentives to break bureaucratic rigidity, and the people's consent to use resources, as well as sound institutions and higher levels of economic development. Without changes in domestic preferences or resources that are exogenous to domestic institutions and somewhat susceptible to international factors-including changes in power structures, norm diffusion, transactions, and assistance-democratic leaders have little to do beyond supporting current practices in order not to be voted out. Using dynamic ordered probit models, this article assesses whether the democratic effect decreases human rights violations or prevents more violations than current levels. The results indicate that low levels of human rights violations are not more likely to emerge under democratic governments compared to other types of regimes, but low levels of violations are more likely to continue in democracies, which suggest that democratic institutions are effective in maintaining good practices rather than creating them. Demonstrating the limited nature of the democratic effect, this article also lends insight into the alternative causal routes involving international contexts for the improvement of human rights.
\end{abstract}

Key Words: democratic institutions, human rights violations, democratic accountability, checks and balances, Markov transition models

\footnotetext{
*Youngsoo Yu (youngsooyu@korea.ac.kr) is Research Professor at the Graduate School of International Studies (GSIS), Korea University. He received his Ph.D. degree in Political Science from Binghamton University (SUNY). He has a special interest in the study of institution building and human rights practices in transition countries. This article is a modified version of a chapter of the author' s doctoral dissertation, "Democracy and Human Rights Protection: Rethinking and Re-examining Their Relationship," 2014, Binghamton University. This work was supported by the National Research Foundation of Korea Grant funded by the Korean Government (NRF-2016S1A3A2925085).
}

The Korean Journal of International Studies Vol.14, No.3 (December 2016), 415-446.

http://dx.doi.org/10.14731/kjis.2016.12.14.3.415

() 2016 The Korean Association of International Studies 
$\mathbf{T}$ he empirical association between democracy and the protection of human 1 rights has been one of the most important and robust findings in human rights research (Davenport 2007). However, the democratic effect has also been doubted as many emerging democracies were found to be unconcerned about, or even irresponsible and incompetent in protecting human rights (Kaplan 2002; Mann 2005; Mansfield and Snyder 2005; Zakaria 2003). This pessimistic outlook has been further strengthened in recent years as human rights have been undermined in favor of many issues related to security and economic development even in many advanced democracies, such as Hungary, Poland, and South Korea (Amnesty International 2015).

As a matter of fact, there is little evidence that increased democracy reduces human rights violations in a country. The empirical evidence found in previous studies is almost all about a cross-sectional relationship. A recent study found that the estimated relationship between democracy and human rights violations in the literature was found to be driven by between-country variations and there were no significant within-country effects (Armstrong 2009). Unless the withincountry relationship is confirmed, the causal effect of democracy on human rights violations is still questionable. A more serious challenge in confirming the causal effect of democracy is to explain about major human rights improvements in countries at the lower end of democracy indices. In many of the emerging democracies in the 1980 s and 1990s, including Poland, Taiwan, Mongolia, and South Africa, serious human rights violations already were not occurring or were decreasing while their democratic institutions were still being built or even when they did not exist, which suggests that human rights progress may not be the result of the good work of democratic institutions.

How then is the robust correlation between democracy and human rights violations to be explained? Why do some countries improve their human rights practices at the lowest or modest levels of democracy? Why do other countries continue to repress their people even after democratization? How can various types of links between democracy and human rights violations in different groups of countries be systematically explained? There are many possible interpretations for the discrepancy between the within-country and between-country effects of democracy. For instance, it could be the case that democracy does lead to better human rights protections but needs longer time periods to take effect (Armstrong 2009). The democratic effect in a country may not be shown in the short run but could appear in the longer run. It is also possible that the relationship could be a spurious association driven by the same determinants such as culture, wealth, economic norms, and other unknown factors (Bova 2001; Mousseau and Mousseau 2008; Pierskalla 2010). Given the complex causal links among democ- 
racy, human rights violations, domestic socio-economic and cultural factors, and numerous international factors, it is probable that something that encourages leaders to create democratic institutions also encourages them to protect human rights or discourages them from violating human rights.

This article offers another interpretation, backed by statistical evidence, that democracy and human rights violations are negatively associated not because low levels of human rights violations are more likely to emerge in democracies, but because low levels of violations can occur under any type of regime but are more likely to continue in democracies. Other than democracy, socio-economic conditions such as wealth and a vibrant civil society, political conditions like having a potent bureaucracy and rule of law, and international environments and pressure from other countries, all contribute to good human rights practices. Under various combinations of such conditions, democratic institutions and good human rights practices could come into existence almost at random, rather than being driven by the same single factor. The mechanisms of democratic institutions, such as competition and contestation, checks and balances, and participation, certainly make democratic leaders accountable for their behavior toward constituencies and other elites. However, these mechanisms only force leaders to keep to good human rights practices when they have already instituted those good practices, but they are not enough to provide an impetus for human rights reforms that usually require all-out rebuilding of entire political, economic, and social systems.

In order to improve human rights practices, governments need to replace their repressive governing methods with non-repressive ones, which requires major reforms of the police, intelligence community, military, judiciary, prison system, governmental relations with business and labor, ethnic policies, and so on. Those reforms cannot be successful without a government capacity to deter or reconcile with the opposition against such reforms, rationales and incentives to overcome bureaucratic inertia, and the people's consent to use resources in sacrifice of other policy goals, to say nothing of having sound political and social institutions and measurable economic development. Citizens, and government agents especially, may not support reforms if other policy goals are affected, and, democratic leaders may give up initiating or continuing those reforms if they do not help them win the next election.

When a country has been suffering from chronic violations of human rights due to its political system or deep-rooted violent threats, it may be hard even for a democratic government to successfully carry out human rights reforms and escape from a vicious circle of repression without the help of external factors, such as large-scale political upheavals or something that puts a stop to violent dissent 
(Call 2002; Conrad and Moore 2010; Hafner-Burton and Ron 2009). Democratic elements such as democratic accountability and checks and balances do not guarantee successful human rights reforms and, at best, keep governments from further violations. The impetus for changes may come from outside of domestic political processes.

In order to investigate the two separate effects of democracy-decreasing human rights violations and sustaining current levels-this article uses Markov transition models, which allow us to distinguish between the probability of emergences of low levels of violations and the probability of their continuations, and provides an empirical answer to the question of whether democratic institutions discourage governments from both initiating and continuing human rights violations. An advanced technique using cumulative transition probabilities as a dependent variable with more than two higher-dimension categories-a technique developed by Clayton (1992) and implemented by Epstein et al. (2006) in political science research-enables us to examine transitions between three states of human rights violations. This article estimates the effects of democracy and its various elements on human rights violations on six types of transitions across three states: high-tomedium, medium-to-low, and high-to-low levels of human rights violations, as well as the three reverse transitions.

The rest of this article is organized as follows. The next section provides a brief review of the existing literature on democracy's effect on human rights protections and then discusses the difficulties of causal inference in empirical studies in the literature. In the following two sections, two different effects of democracy on human rights violations are introduced to explain why democratic institutions are more associated with prevention of more violations than a decrease in the number of violations. The remaining sections describe the data, discuss the estimation methods, and present the empirical results. Finally, conclusions on the implications of this article for the literature on democracy and human rights are drawn.

\section{DEMOCRATIC INSTITUTIONS AND HUMAN RIGHTS VIOLATIONS}

\section{INSTITUTIONAL EXPLANATIONS OF THE DOMESTIC DEMOCRATIC PEACE}

There are three mechanisms through which democracy is thought to reduce human rights violations. First, compared to other types of governments, democratic governments have more accountability because leaders chosen through democratic competitions on a regular basis have more pressures from domestic 
constituencies who prefer strong human rights protections. In democratic governments that are composed of accountable and representative institutions, leaders who commit human rights abuses are more likely to be deposed from their positions by popular control. Therefore, democratic leaders are more likely to support strong human rights protections in order not to be voted out (Bueno de Mesquita et al. 2005; Davenport 1999; Poe and Tate 1994).

Second, democratic governments develop more institutional checks and balances on the executive than other types of governments, and leaders in the executive cannot change human rights policies easily by fiat. Within democratic political systems, there exist political actors who can curb the decision-making power of chief executives, usually elected members in the legislature and independent office holders (including elected ones) in the judiciary (Tsebelis 2002). Leaders in the executive branch need cooperative relationships with elites in other branches for their policies to be realized through legislation, and not to be hampered by judicial rulings. If they pursue repressive policies or actions unilaterally against the will of other elites, the confrontation is likely to end in non-cooperative relationships that possibly would prevent the successful implementation of other policies. Democratically-elected elites in the executive branch concern themselves not only with electoral success or failure, but also with resistance or future non-cooperation as a punishment from elites in other branches of government when they contemplate repressive policies or actions (Davenport 2007).

Third, democratic governments are less likely to violate human rights because they develop non-violent means to deal with domestic disputes and citizens also are socialized to voice their demands through peaceful means (Mitchell and McCormick 1988). Thus, democratic governments do not view dissidents as threats (Regan and Henderson 2002). For the virtuous circle of non-violent input and output in the democratic political process, not only such government institutions as elections, participation through parties, and policy votes by way of referendum, but also social mechanisms like norms, organizations, and culture make governments and the people responsive and responsible to one another, respectively. Civil society is particularly important in making political processes work. Civil society can shape public opinion to give feedback about government policies or practices and reinforce monitoring of government human rights practices through the media or civil organizations (Poe and Tate 1994).

\section{CRITICISMS OF DOMESTIC DEMOCRATIC PEACE THEORY}

"Domestic democratic peace" theory turns out to be less tenable when exposed to numerous criticisms and, as often expressed by those critics, democracy may not be the prime cause of better human rights protections. Previous research has 
shown that there is much diversity among both democracies and autocracies. Transitional democracies are more prone to repression than stable democracies and even stable autocracies (Fein 1995). Furthermore, human rights abuses often continue even after democratic consolidation (Diamond 1996). Democracy without constitutional liberalism, and liberal institutions to support it, leads to human rights abuses (Zakaria 1997). The effects of liberal democratic institutions on various forms of repression are limited when violent dissent exists (Conrad and Moore 2010; Davenport 2007). Furthermore, wealthy autocracies may respect the rights of their citizens (Sobek, Abouharb and Ingram 2006). Protections of individual rights have more to do with the social development of liberal institutions in "market societies" than what is the domestic regime type (Mousseau and Mousseau 2008). Transnational human rights pressures and policies make a significant difference in diverse countries around the world (Risse and Ropp 1999), and partial or transitional democracies with a modest degree of institutional accountability and political participation are more likely to improve their human rights practices than stable democracies and stable autocracies when they bind themselves to international human rights norms (Simmons 2009).

These criticisms can be summarized by two points. First, democratic institutions do not necessarily bring decreases in human rights violations. In a theoretical sense, democracy is not a sufficient condition for human rights improvement; in an empirical sense, the causal effect of democracy on human rights violations could be unclear because both positive and negative effects of either regime type cancel each other out. It is not difficult to find mixed effects across countries. Second, decreases in human rights violations do not necessarily occur under democracy. Many factors other than democracy also constitute the conditions for better human rights practices. Some non-democratic regimes made progress in their human rights practices as they liberalized their economies and opened their societies even though their political transitions to democracy had not yet occurred. The well-established argument that democracy is a necessary condition for human rights improvements should be called into question. ${ }^{1}$

\footnotetext{
${ }^{1}$ Many studies, especially on the influence of international factors on human rights practices, provide empirical evidence supportive for this point. Several Eastern European countries, such as Poland and Hungary, began to improve their human rights protections when they started to expand their security, human rights, and economic cooperation with Western Europe (Domber 2013; Drake 1998; Forsythe 2012). Taiwan, Mongolia, and South Korea tolerated opposition and began to expand civil liberties not based on democratic accountability but from their elites' diplomatic considerations of security and economic prosperity in changing environments (Diamond 2008; Hsiao and Koo 1997). Lastly, international interventions or multilateral peacekeeping operations have eliminated autocratic regimes that do not respect the rights of other states as well as their own people (Meernik 1996)
} 


\section{DECREASING AND PREVENTING VIOLATIONS}

While previous research argues that human rights progress occurs at the highestlevels of democracy after a long period of transition and consolidation, in actual cases, including the countries listed above, major decreases in human rights violations are observed under any type of regime at an almost equal rate. Table 1 reports some descriptive patterns of more than 180 countries between 1978 and 2005. It shows the number of cases and probabilities of human rights changes between high, medium, and low violations at different levels of democracy. ${ }^{2}$ Altogether, there were 5,516 country-year observations: 2,400 observations of a low level, 1,285 observations of a medium level, 842 observations of a high level of human rights violations, and 989 observations with missing data. Six different changes were possible: from high to medium, from medium to low, from high to low, and the three reverse changes. There were 75 cases of transition from a high to a medium level of violations, 87 transitions from a medium to a low level, 7 from high to low, 118 from low to medium, 92 from medium to high, and 19 from a low to a high level of violations. The regime type is categorized using the oneyear-lagged 21 point-scale Polity $I V$ regime indicator.

Three levels of human rights violations are found at any level of democracy, and human rights changes occur across the levels. As shown in column (1), the average probability that human rights violations decrease from a high to a medium level at any level of democracy is .089 and does not vary to a great extent across democracy levels. The probability is .090 when a country is an autocracy, .080 when a country is a mixed regime, and .098 when a country is a democracy. As shown in column (2), the average probability of a change from the medium to the low level is .068, and it appears that the probability is higher in democracies than in non-democracies. The probability is .062 in autocracies, .040 in mixed regimes, and .108 in democracies. Direct transitions from a high to a low levelwhich are rare events-occur more often in non-democracies than democracies.

and enable countries mired in civil war to stop violent conflicts, restore order, and improve human rights (Murdie and Davis 2010). In the cases of Japan and Germany after World War II, their egregious human rights violations were stopped by the post-war interventions of Western powers, and their good human rights practices were built before their own democratic institutions were in working order. More recently, multilateral interventions, including United Nations Peace Keeping Operations (UNPKOs), have brought human rights improvements in many countries such as Mali, East Timor, Bosnia and Herzegovina, Croatia, Guatemala, and El Salvador, which improved their human rights practices resulting from international surveillance and assistance programs for reconstruction.

${ }^{2}$ The three states of violations are coded from the Political Terror Scale (PTS) data. The coding scheme is described below. 
Table 1. Frequency of Human Rights Changes by Level of Democracy

\begin{tabular}{|c|c|c|c|c|c|c|c|c|c|c|c|}
\hline \multirow[b]{4}{*}{ Regime Type } & \multirow[b]{4}{*}{ Total } & \multicolumn{10}{|c|}{ Human Rights Changes } \\
\hline & & \multirow{2}{*}{\multicolumn{4}{|c|}{ Violations }} & \multicolumn{2}{|c|}{ Decrease in Violations } & \multicolumn{4}{|c|}{ Increase in Violations } \\
\hline & & & & & & (1) & (2) & (3) & (4) & (5) & (6) \\
\hline & & High & Med & Low & N/A & $\mathrm{H} \rightarrow \mathrm{M}$ & $\mathrm{M} \rightarrow \mathrm{L}$ & $\mathrm{H} \rightarrow \mathrm{L}$ & $\mathrm{L} \rightarrow \mathrm{M}$ & $\mathrm{M} \rightarrow \mathrm{H}$ & $\mathrm{L} \rightarrow \mathrm{H}$ \\
\hline Autocracy & 1443 & 279 & 566 & 516 & 82 & $25(.090)$ & $35(.062)$ & $1(.004)$ & $57(.110)$ & $33(.058)$ & $6(.012)$ \\
\hline Mixed & 987 & 327 & 372 & 250 & 38 & $26(.080)$ & $15(.040)$ & $4(.012)$ & $27(.108)$ & $33(.089)$ & $8(.032)$ \\
\hline Democracy & 1724 & 183 & 295 & 1201 & 45 & 18(.098) & $32(.108)$ & $1(.005)$ & $31(.026)$ & $20(.068)$ & $4(.003)$ \\
\hline N/A & 1362 & 53 & 52 & 433 & 824 & 6 & 5 & 1 & 3 & 6 & 1 \\
\hline All & 5516 & 842 & 1285 & 2400 & 989 & $75(.089)$ & $87(.068)$ & $7(.008)$ & $118(.049)$ & $92(.072)$ & $19(.008)$ \\
\hline
\end{tabular}

- 'Regime Type' is categorized based on the 21 point-scale combined indicator of regime type from the Polity $I V$ dataset. I use the standard threshold in which countries scoring -6 and below are categorized as autocracies, countries scoring between -5 and 5 as mixed regimes, countries scoring 6 and above as democracies. The detailed results at each level of the 21 point-scale indicator are available from the author.

- 'Total' stands for the total number of observations.

- A country is thought to experience a transition when that country moves between three states, high (4 or 5 of the PTS score), medium (3), or low level (1 or 2) of human rights violations.

- The number in parenthesis is the probability of the transition at a given level of democracy.

The effect of democracy on the probability of human rights changes will be assessed in sophisticated models with controls later in this article.

On the other hand, increases in human rights violations occur much less frequently in democracies than in non-democracies. The probability of increases in human rights violations from the low to the medium and from the low to the high levels is much higher in non-democracies than in democracies. Column (2) and (3) in Table 1 show the probabilities that human rights violations increase across the levels of democracy. The average probability at any level of democracy is .049 for the change from the low to the medium level, .072 for the change from the medium to the high level, and .008 for the direct change from the low to the high level. When a country is an autocracy, the probabilities of changes are .110 (low to medium), .058 (medium to high), and .012 (low to high directly); when a country is a mixed regime, the probabilities of changes are .108 (low to medium), .089 (medium to high), and .032 (low to high directly); and, when a country is a democracy, the probabilities are .026 (low to medium), .068 (medium to high), and .003 (low to high directly).

The descriptive patterns reported here are quite contrary to the arguments and findings from previous studies. If decreases in human rights violations result from development of democratic institutions, as previous studies argue, decreases of violations should be more likely to occur at higher levels of democracy, or at 
the highest levels of democracy as predicted in recent empirical analyses. The descriptive patterns here, on the contrary, show that changes to lower levels of human rights violations occur at any level of democracy, and changes to higher levels of violations are more likely to happen at the low or the medium level of democracy.

What do the empirical regularities say about the association between democracy and human rights violations? This study adopts the logic of endogenous and exogenous modernization developed by Przeworski and Limongi (1997) ${ }^{3}$ and tries to explain why and in what ways democracy and human rights violations are associated. The endogenous explanation of the democracy-human rights association is that lower levels of human rights violations are more likely to be achieved as a result of the development of democracy. One of the descriptive patterns that lower levels of human rights violations emerge at any level of democracy is not consistent with the endogenous explanation but supports the first half of the exogenous explanation: a lower level of human rights violations comes from reasons other than democracy. Furthermore, the other pattern that changes to higher levels of human rights violations occur more frequently in non-democracies turns out to be in favor of the latter half of the exogenous explanation: a lower level of violations survives under democracy.

\section{THEORETICAL ARGUMENTS: WHY DOES DEMOCRACY NOT REDUCE VIOLATIONS?}

Based on the empirical regularities discussed in the previous sections, I argue that democratic institutions do not reduce human rights violations but keep governments from violating human rights more than current levels because people-at least the majority of constituencies, elites, and leaders-do not want to pursue

\footnotetext{
${ }^{3}$ Przeworski and Limongi (1997) distinguish two different explanations from modernization theory: countries are likely to become democracies as they develop economically, and rich countries are more likely to sustain democracy (Lipset 1959). The former is called an endogenous explanation in the sense that democracies are more likely to emerge as a consequence of economic development and the latter an exogenous explanation in the sense that democracies may emerge for reasons other than economic development but are more likely to survive in developed economies. Providing empirical evidence from various statistical models, it is concluded that democratization occurs randomly but, once established, is less likely to fail at higher level of economic development (Przeworski and Limongi 1997; Przeworski et al. 2000).
} 
human rights reforms in sacrifice of other policy goals and values, such as economic growth and ethnic domination. They are thought to prefer better human rights protections but may not like the policies chosen to achieve those protections. It may be hard for them to find other ways that do not incur damages to other policy goals and values. The caveat is that a government is concerned with a multiplicity of policy fields, not just human rights. Likewise, voter preferences are shaped by more than just perceptions of their government's human rights policies. Human rights policies are made under various kinds of constraints such as government budgetary limits, conflicts of interests among constituencies as well as among government agencies, and cognitive biases in favor of the status quo.

\section{BASIC ASSUMPTIONS}

Firstly, I assume that any government move for an improvement in human rights should always come with organizational reforms or policy changes. In order to improve human rights practices, governments have to adjust the size and roles of the organizations that are present or potential threats to human rights. Government organizations including the police, military, and intelligence, which served the purpose of regime security in the past autocratic rule or fought against internal or external enemies in past conflicts, have to be reduced in size and roles. On the other hand, the judiciary and human rights organizations should be created or reinforced to guarantee access to the judicial system, judicial independence including the independence of judges and prosecutors, and accountability for human rights abuses. For better protection of physical integrity rights, governments need to change their policies on such issues as investigation, prosecution, incarceration, and dissent, including organized protest and civil disobedience. If minority rights are in question, a far broader range of government policies have to been acted. For instance, use of minority languages should be ensured, equal opportunities in education and employment, access to public services, and political participation should be guaranteed, and rights for ethnic cultures should be granted. Protections of economic, social, and cultural rights covers the whole gamut of government policies, including housing, health care, labor, and religion.

The second assumption is that organizational reforms and policy changes require government resources, and the use of any amount of those resources for human rights improvements sacrifices other policy goals within a limited amount of available resources (Hafner-Burton 2013; Holms 1999; Simmons 2009). When a government allocates its resources to human rights reforms, it makes decisions in balance with other goals within its budget constraints. The more resources a 
government allocates for human rights reforms, the fewer resources will be left for the achievement of other policy goals. Government allocation of resources to human rights reforms is restrained by other policy goals within the entire amount of government budgets. In sum, a government' s actions regarding human rights in everyday political situations is strongly influenced more by budget allocation issues than decisions to use or not to use violence in emergencies.

\section{DIFFERENCES IN PREFERENCES}

The first reason why it is not easy even for democratic governments to succeed in human rights reforms is that the majority of citizens may not want human rights reforms if those reforms precipitate sacrifices of other goals and values. People want better human rights protections but they also want their governments to achieve other goals such as economic growth, social welfare, and public safety. Not all, but many people think that there are trade-offs between human rights and other values and civil liberties, and personal freedoms could be restricted to ensure the achievement of other values such as security and safety (Davis and Silver 2004). The main problem is that available resources are limited. Unless more resources are available, or people's preference structures change, resources allocations will not change. Democratic leaders, who know that their chances to be reelected are determined by their overall performance-not by human rights practices alone-want to maximize the probability of winning elections by trying to meet the policy demands of the coalitions they will need to win elections when those resources are limited.

When more complex pictures of democracy incorporating partisan politics and state-society relations are considered among a broad range of human rights issues, human rights reforms seem to be subject to the political interests of the majority, key players, or organized groups, rather than the imaginary homogenous preference for better human rights protections. Human rights policies could be the result of partisan politics to acquire majority support within a complex web of issue agendas. Ahnen (2007) argues that the trade-off between effective control of crime and human rights protection affects both candidate positions and voter choices, regardless of whether a real trade-off actually exists or not. He finds that arbitrary uses of police violence are associated with the political ideology of governors in Brazilian states and suggests that "members of a society do not necessarily share an equal interest in promoting the effective guarantee of physical integrity rights for all citizens" (Ahnen 2007, 160). Another example of human rights in partisan politics is the delay of civil rights legislation due to the changing alignments around various issues among Southern Democrats, non-Southern Democrats, and Republicans in the United States in the 1950s and early 1960s 
(Lijphart 1977). These examples suggest that human rights issues are only a part of political agendas, and elites and voters align themselves with various set of causes and values according to their interests.

Second, state-society relations also affect government decisions regarding human rights policies. Htun (2003) finds that most liberal legislative initiatives concerning women's rights took place during autocratic rule than during democratic governments in Argentina, Brazil, and Chile. She explains that democratization makes both liberal and illiberal mobilization possible, and that liberal groups have to overpower conservative groups to successfully achieve reforms. According to her analysis of the improvement in women's rights, it was the stateCatholic Church relationship that made the difference in those three Latin American countries. Liberal reformers in democratic regimes failed to legalize women's rights issues when their states and the Catholic Church were in a cooperative relationship. Politicians did not want to confront the Church. In contrast, pro-modernization groups in autocracies could make use of the conflictive relationship between their autocratic regimes and the Church. She concludes that the success of liberal policy change is "not the automatic triumph of democracy but a result of shifts in power configurations that overcome the status quo" (Htun 2003, 173).

\section{RESISTANCE FROM BUREAUCRACY}

The second reason why human rights reforms may fail to succeed is that democratic leaders have to deal with resistance from government agencies that comes from a cognitive bias against change, disagreement over policy goals, or an organizational propensity to maintain their existence or status. On the one hand, government agencies may stand up for their own policy interests and values other than human rights and reject reforms that do harm to those policy interests and values. When an attempt is made to replace one policy with another, pro-reform coalitions and anti-reform coalitions may be mobilized in and out of government. Both coalitions can be joined by government officials, expert groups, and organized interest groups, and contest with each other over economic, technical, and moral grounds aside from the original policy goals. For instance, the National Security Law of South Korea, which encroaches on such civil rights as freedom of thought and freedom of expression for the reason of defending South Korea against North Korean espionage and infiltration, has survived many attempts to repeal it since the South's democratic transition in 1987 (Jaung 2009). Although the legitimacy of the law has been undermined drastically as South Korea increased political, economic, and cultural exchanges with North Korea, government agencies in the security and intelligence sectors, and conservative groups 
including politicians, media, and evangelical churches, have successfully resisted overturning of the law. Another example is the compulsory isolation of patients with Hansen disease in many countries, which continued for several decades after effective treatments of the disease were found in the 1940s and scientific research confirmed that the contagion could be effectively controlled; and this even lasted after the World Health Organization repeatedly recommended the abolishment of pro-isolation policies (Sato 2002). "Prolonged policies institutionalized patients for a period longer than scientific knowledge justified" (Sato 2002, 30). In Japan, the law for forceful isolation was repealed in 1996, and in the United States the law was terminated in 1985. According to Sato (2002), inattention or disregard from the public, politicians, legal professionals, an intellectual reluctance to accept opinions from medical experts, organizational inertia, and coalitions against abolition contributed to the survival of the policy for such a long time.

On the other hand, government organizations have an inertial tendency to maintain their existence and position within government (Poe et al. 1999). Governments make decisions about repressive actions based on information about their coercive apparatus, its past capacity, and its present preparedness. Increased capacity may bring about an increase in repressive actions (Davenport 1996). Military or security forces are not easily disbanded once they are put into place (Carey 2006). In many countries, paramilitary groups formed for security reasons were at the forefront of human rights abuses during and after the military conflicts for which they were formed. Paramilitary troops often are not held accountable for their human rights crimes, and governments often have little control over them and may even give them the role of civilian law enforcement. ${ }^{4}$

\section{DATA}

\section{DEPENDENT AND MAIN EXPLANATORY VARIABLES}

The dependent variable of this empirical analysis is a three-state ordinal variable of human rights violations. ${ }^{5}$ I assume that one may recognize government human

\footnotetext{
${ }^{4}$ See, for example, Human Rights Watch (2013).

${ }^{5}$ The measurement of human rights practices is not within the scope of this article. The author, keenly aware of the advantages and disadvantages of diverse measures, adopts the PTS indicator, the most frequently used measure, and collapses the five-point scale indicator into a three-state ordinal variable.
} 
rights practices as a discrete ordinal variable rather than a continuous one, and that a country's human rights practices in a given year is not independent of the country's practices in the past. Thus, changes in a discrete ordinal variable in the presence of temporal dependence can be analyzed as a Markov chain process of transition between different states over time. In this article, I examine human rights changes between three possible states: high, medium, and low levels of human rights violations. The dynamic ordered probit method, as developed thus far, allows researchers to examine transitions between no more than three states. Using the PTS indicator, which scales human rights violations from 1 to 5 , I categorize human rights violations into three states. ${ }^{6}$ A country-year observation is coded as low level' when a country maintains the two lowest scores (1 or 2) of the PTS indicator for at least three consecutive years, as 'medium level' when a country scores 3 for three years in a row or fails to keep the two lowest PTS scores for three years and moves down to 3 , and as 'high level' when a country scores 4 or 5 at any time. I decided whether a country passed a threshold on the basis of three-year observations to exclude temporary episodes of human rights improvement but did not apply this rule to human rights declines. The basic idea of this coding scheme is that a period of good human rights performance does not equate to progress, though even short-time abuses are counted when making a determination as to whether a country is rights-protective or not.

The main explanatory variable employed here is democracy. This analysis relies on the Polity IV dataset, which is thought to reflect institutional features of democracy, whether combined or separated. As in previous studies, this analysis mainly examines the effects of democratic institutions. The analysis of separate elements of democracy would have a great importance on an understanding of how various mechanisms of democratic institutions affect human rights practices in different ways. Some aspects of democracy may fail to induce governments to reduce human rights violations but may prevent them from further violations.

\footnotetext{
${ }^{6}$ I use the PTS indicator because this five-point scale score is easy to be converted to a three-state categorical variable. Authors consider scores of 1 or 2 as low levels of repression (violations), 3 as a medium level, and 4 or 5 as high levels (See, for example, Davenport 2004; Keith and Poe 2004; Poe et al. 2000; Walker and Pearson 2007). In contrast, the Cingranelli and Richards Physical Integrity Rights Index (CIRI) is not easily converted. The index is a nine-point scale score ranging from o to 8 and based on the four three-state categorical indicators of government respect for physical integrity rights; that is, the rights codified against torture, summary execution, disappearance, and political imprisonment. It is not easy to create a three-state categorical variable out of the sum of four threestate categorical variables. It would be arbitrary to set two cut points between $\mathrm{o}$ and 8 or use averages of the four variables. An appealing way could be to use four respective indicators but it does not provide the whole picture. The results with separate indicators are available from the author.
} 
For instance, the veto mechanism of democratic institutions may not be helpful for reducing human rights violations but may have an impact on preventing a greater number of violations. The veto mechanism, rather, is associated with a status quo policy (Tsebelis 2002; Conrad and Moore 2010) and hinders any change in either direction. Three different measures of aggregate multi-dimensional democracy are used: a 21 point-scale combined score; an 11 point-scale democracy score; and a trichotomous democracy score as suggested by Davenport and Armstrong (2004) for detecting a curvilinear relationship with a threshold. The sub-components of institutionalized democracy are also investigated, and here I use the three variables of executive recruitment, executive constraints, and political competition. I use them in their original measurements and also modify them into trichotomous variables following the method used by Davenport and Armstrong (2004) to create a three-state measure of democracy by observing LOWESS estimates of the effect of each sub-component variable and deciding the three different categories, each of which has a different effect on the dependent variable: a category of no effect, some negative effect, and a strong negative effect. ${ }^{7}$

\section{CONTROL AND ADDITIONAL EXPLANATORY VARIABLES}

The control variables are selected based on two contradictory considerations. First, I try to include as many variables as possible to mitigate the bias from omitting potential confounders. Second, I try to build models as simple as possible because all the explanatory variables should have interaction terms with two dummy indicator variables for past violations. Thus, I conducted numerous regressions and simple ordered probit analysis-as well as Markov probit estimations-with a variety of control variables to check whether they influence the significance of democracy and whether they improve the explanatory power of the models. Five standard control variables were selected: economic development, civil conflict, international conflict, population size, and past human rights violations. Other than the five control variables, I found that none of the standard control variables in human rights research seriously affects the baseline result of this analysis. Economic development is measured by GDP per capita. The Lacina and Gleditsch (2005) data on battle deaths in civil and international wars are used for the two variables of civil and international conflict. A one-year lagged dependent

${ }^{7}$ For the executive recruitment variable, the LOWESS result suggests that the variable has a Ushaped relationship to human rights violations rather than a curvilinear relationship with a threshold. I regressed the dependent variable on executive recruitment and its square instead of its trichotomous measure. 
variable is included in baseline models to control for past violations. In Markov transition models, the variable is split into two binary indicator variables of which combinations indicate three states of past violations.

Some variables explored in recent empirical studies were also considered for comparisons with democracy about how they work, as well as for more controls. Through extensive observations and analyses, studies in the human rights literature have found that a potent bureaucracy, an uncorrupted political system, an open economy, a vibrant civil society, and participation in intergovernmental organizations-as well as democracy, economic development, and internal and external peace-all contribute to favorable conditions for greater human rights protection. Five variables are included in the models. Due to multicollinearity among these new variables, each expanded model includes only one new variable. State capacity to police territory and control state agents is important to human rights protection (e.g., Englehart 2009). On the contrary, democracy without successful state-building may not help to prevent human rights disasters (Fukuyama 2004). State capacity is divided in two concepts: control of territory measured using tax revenue per GDP and control of agents measured by corruption indicators from the International Country Risk Guide (ICRG) data. Trade expands the prospect of better human rights practices through economic development or facilitates the diffusion of human rights norms through pressure from consumers and activist groups in importing countries directed towards exporting countries (Cao et al. 2013). Trade is measured by the ratio of trade to GDP. A strong civil society makes the political process work and pacifies domestic dissent. The number of international nongovernmental organizations (INGOs) as measured by Wiik (2002) is used as a measure of civil society. Participation in NGOs (INGOs) in itself, not as a proxy variable of civil society, is important in adoption of, and mobilization for, international human rights norms (Brysk 1994; Risse, Ropp, and Sikkink 1999). Countries exchange ideas, discuss the adoption of policies, compare one another's performances, and emulate behaviors among self-identified peers in intergovernmental organizations (Greenhill 2010). I use the human rights violations of partners in IGOs as a measure of the intergovernmental organization effect. ${ }^{8}$

8 I constructed the variable following the work of Greenhill (2010). The only difference was that I used the PTS data instead of the CIRI data. First, using the Correlates of War (COW) Intergovernmental Organization data and the PTS data, I computed the human rights violations of each IGO for a country in a given year with the average human rights score of all other member countries in the organization except the country of interest. Each country then has the human rights scores of all the IGOs that it belongs to. Next, I calculated the mean of those scores and named it the intergovernmental organization effect. 


\section{ESTIMATION STRATEGY}

One of the main concerns of this article is to assess the causal effect of democracy on human rights violations. Standard procedure in human rights research is to use the ordinary least squares (OLS) method or the maximum likelihood estimation (MLE) of ordered logit or probit without country-fixed effects, which are not relevant to test causality. Furthermore, popular methods to assess a causal relationship may not work here for various reasons. First-difference regression is a simple method to see if the relationship between democracy and human rights violations is causal or not, but this method seems to be inappropriate because the speed with which democratic changes affect human rights violations varies to a great extent from country to country. Some countries such as the Czech Republic and Uruguay showed a significant change in human rights violations from their first year of democratization, while other countries such as Brazil, Turkey, and the Philippines experienced decades of struggle for better human rights protections. The panel fixed-effect regression is an appealing strategy in many cases in the sense that the method controls all time-invariant variations across countries. However, it is less appropriate when there is attenuation bias from measurement error in persistent regressors like democracy. Variation of human rights violations over years under a stable level of democracy/autocracy would be seen as noise rather than a result of the consistent effect of regime type. In addition, fixed effect estimation can only control for time-invariant effects but not for time-variant effects. If there are time-variant omitted factors, instrumental variable estimation would be a better method. As for the instrumental variable method in the study of democratic effects, however, many previous studies have recognized that it was very hard to find a suitable instrument for measuring democracy (Treisman 2007). Also, given the extensive causal links from and to democracy-domestic socio-economic conditions, international pressure from norms and organizations, and human rights violations-it would be extremely difficult to find an exogenous variation of democracy unrelated to human rights violations.

The other concern of the empirical analysis of this study is to detect the different impacts of the explanatory variable on upward and downward movements of the dependent variable. Considering the descriptive patterns reported, it is possible that decreases in democracy cause increases in human rights violations, while increases in democracy do not cause decreases in human rights violations. Neither the first-difference method nor the panel fixed-effect method is able to distinguish the two different kinds of associations. The dynamic ordered probit models with a Markov-transition approach utilized in this article are particularly useful to show how differently democracy affects increases and decreases in 
human rights violations, as well as to identify the causal relationship.

This research tests two main hypotheses with regards to democracy and human rights violations: first, the more democratic a country is, the more likely it decreases human rights violations over time; second, the more democratic a country is, the more likely it remains at the current level of lower violations. In order to confirm this article's arguments, the first hypothesis for endogenous explanations that human rights violations decrease under democracy has to be dismissed and the second hypothesis for the exogenous explanation that low levels of violations are more likely to continue under democracy should be accepted. For the estimation of the likelihood of the emergence of higher or lower levels of human rights protections-which is separate from the likelihood of remaining at each level-previous conditions should be considered in our estimation. As a method to take previous conditions into consideration, the statistical models will follow the Markov chains function, which makes the present level of human rights protection dependent on the past level. This study adopts a first-order Markov process, which only considers the conditions of the previous year and not beyond. A usual Markov transition model between two states over time can be constructed by running interactions of all explanatory variables with the lagged value of the binary dependent variable. In this analysis, however, the lagged values of two binary indicators of which combinations signify cumulative probabilities to the three-state discrete variable for the previous year's conditions are used so that likelihoods of transitions across three states over time can be estimated. ${ }^{9}$ The following equation is estimated in this analysis:

$$
\begin{aligned}
\operatorname{Pr}\left(Y_{i t}=b\right)= & \Phi\left\{\beta_{0}+\beta_{1} y_{0}^{*}+\beta_{2} y_{1}^{*}+\gamma_{0} \text { Democracy }+\gamma_{1} \text { GDPpc }+\gamma_{2} \text { Population }+\right. \\
& \gamma_{3} \text { CivilConflict }+\gamma_{4} \text { Int'l lConflict }+\gamma_{5} y_{0}^{*} \text { Democracy }+\gamma_{6} y_{0}^{*} \text { GDPpc }+ \\
& \gamma_{7} y_{0}^{*} \text { Population }+\gamma_{8} y_{0}^{*} \text { CivilConflict }+\gamma_{9} y_{0}^{*} \text { Int'lConflict }+\gamma_{10} y_{1}^{*} \text { Democracy }+ \\
& \left.\gamma_{11} y_{1}^{*} \text { GDPpc }+\gamma_{12} y_{1}^{*} \text { Population }+\gamma_{13} y_{1}^{*} \text { CivilConflict }+\gamma_{14} y_{1}^{*} \text { Int'lConflict }\right\}
\end{aligned}
$$

In the equation, $\operatorname{Pr}\left(y_{i t}=b\right)$ means the probability that a country's level of human rights violations reaches one of the three states(high violations $=0$, medium violations $=1$, low violations $=2$ ) in a given year $\mathrm{t} ; \boldsymbol{\Phi}($.$) is the cumulative normal dis-$ tribution function; $y_{o}{ }^{*}$ and $y_{1}{ }^{*}$ are the two binary indicators of which combina-

\footnotetext{
${ }^{9}$ For more detailed information about the three $\sim$ state markov transition model, see Epstein et al.(2006).
} 
tions are substituted for $Y_{i t-1}$. When $Y_{i t-1}=0, y_{o}{ }^{*}=1$ and $y_{1}{ }^{*}=1$, and thus the coefficient for democracy is $\gamma_{0}+\gamma_{5}+\gamma_{10}$; when $Y_{i t-1}=1, y_{0}{ }^{*}=0$ and $y_{0}{ }^{*}=1$, and the coefficient for democracy is $\gamma_{0}+\gamma_{10}$; when $Y_{i t-1}=2, y_{0}{ }^{*}=0$, and $y_{1}{ }^{*}=0$, and then the coefficient for democracy is $\gamma_{10}$. The probabilities are estimated with the lagged regressors, the lagged values of two binary indicator variables, and all interactions between the regressors and the indicators. The equation is a combined form to estimate the three separate probabilities- $\operatorname{Pr}\left(Y_{i t}=\mathrm{b} \mid Y_{i t-1}=0\right), \operatorname{Pr}\left(Y_{i t}=\mathrm{b} \mid Y_{i t-1}=1\right)$ and $\operatorname{Pr}\left(Y_{i t}=\mathrm{b} \mid Y_{i t-1}=2\right)$-in a single equation.

\section{RESULTS}

I began the analyses with simple ordered probit models with controls for GDP per capita, population size, war deaths from civil and international war, and the past year's violations. The baseline results reconfirmed the estimations of previous studies. As shown in Table 2, the sign, magnitude, and statistical significance of the coefficients were coherent with previous studies. The coefficients for democracy and its elements were all significant at conventional levels (.05 or .01). The models using trichotomized scores for democracy and its elements have enhanced explanatory and predictive power, as Davenport and Armstrong (2004) have reported. Compared to the linear models, the impact of democracy and its elements and the R-squared value were shown to be greater in threshold models, while the effects of other variables remained identical.

The results of the Markov regression analysis are displayed in Table 3. All regressors and their interactions with two indicators are estimated. All the coefficients for simple regressors without interaction are the estimated effects of explanatory variables on the conditional probability that the previous year's level of violations $=2$ (low). For instance, the effects of democracy measured with an 11 point-scale Polity $I V$ democracy score on the probability that countries remained at the low level of violations was .067 as shown in column (1). The interaction of an explanatory variable with indicatordenotes the difference between the effects of the variable on probabilities of continuation at the low level and the effect on other probabilities as long as the interaction with is statistically significant. For instance, if the interaction between the Polity $I V$ democracy score and was statistically significant, the effect of democracy on transition from the high or the medium level to the low level of violations was different from .067. The difference was equal to the size of the coefficient on the interaction effect if it was significant. In turn, the interaction with indicator shows the difference in the effect on probabilities of transition from the high to the low level and the effect on other proba- 
Table 2. Simple Ordered Probit Results

\begin{tabular}{|c|c|c|c|c|c|c|c|c|}
\hline & \multicolumn{8}{|c|}{ Model } \\
\hline & (1) & (2) & (3) & (4) & (5) & (6) & (7) & (8) \\
\hline Democracy & & & & & & & & \\
\hline $\begin{array}{l}\text { Polity IV Democracy } \\
\text { (11 point scale) }\end{array}$ & $\begin{array}{l}.030^{* * *} \\
(.008)\end{array}$ & & & & & & & \\
\hline Trichotomous Democracy & & $\begin{array}{l}.293^{* * *} \\
(.057)\end{array}$ & & & & & & \\
\hline $\begin{array}{l}\text { Executive Recruitment } \\
\text { (EXREC) }\end{array}$ & & & $\begin{array}{l}.027^{*} \\
(.013)\end{array}$ & & & $\begin{array}{l}-238^{*} \\
(.102)\end{array}$ & & \\
\hline $\begin{array}{l}\text { Executive Constraints } \\
\text { (EXCONST) }\end{array}$ & & & & $\begin{array}{l}.051^{* * *} \\
(.013)\end{array}$ & & & & \\
\hline $\begin{array}{l}\text { Political Competition } \\
\text { (POLCOMP) }\end{array}$ & & & & & $\begin{array}{l}.026^{* *} \\
(.008)\end{array}$ & & & \\
\hline EXREC $^{2}$ & & & & & & $\begin{array}{l}.025^{* *} \\
(.010)\end{array}$ & & \\
\hline Trichotomous & & & & & & & $.163^{* * *}$ & \\
\hline EXCONST & & & & & & & $(.038)$ & \\
\hline Trichotomous POLCOMP & & & & & & & & $\begin{array}{l}.298^{* * *} \\
(.052)\end{array}$ \\
\hline GDPpc & $.049^{* * * *}$ & $.038^{* * *}$ & $.056^{* * *}$ & $.051^{* * *}$ & $.053^{* *}$ & $.048^{* * *}$ & $.048^{* * *}$ & $.039^{* *}$ \\
\hline (in dollar thousands) & $(.008)$ & $(.008)$ & $(.008)$ & $(.008)$ & $(.008)$ & (.008) & $(.008)$ & $(.008)$ \\
\hline Population(ln) & $\begin{array}{l}-.000^{* *} \\
(.000)\end{array}$ & $\begin{array}{l}-.000^{* *} \\
(.000)\end{array}$ & $\begin{array}{l}-.000^{* *} \\
(.000)\end{array}$ & $\begin{array}{l}-.000^{* *} \\
(.000)\end{array}$ & $\begin{array}{l}-.000^{* *} \\
(.000)\end{array}$ & $\begin{array}{l}-.000^{* * *} \\
(.000)\end{array}$ & $\begin{array}{l}-.000^{* *} \\
(.000)\end{array}$ & $\begin{array}{l}-.000^{* * *} \\
(.000)\end{array}$ \\
\hline Civil Conflict & $\begin{array}{l}-.000^{* * *} \\
(.000)\end{array}$ & $\begin{array}{l}-.000^{* * *} \\
(.000)\end{array}$ & $\begin{array}{l}-.000^{* * *} \\
(.000)\end{array}$ & $\begin{array}{l}-.000^{* * * *} \\
(.000)\end{array}$ & $\begin{array}{l}-.000^{* * *} \\
(.000)\end{array}$ & $\begin{array}{l}-.000^{* * * *} \\
(.000)\end{array}$ & $\begin{array}{l}-.000^{* * * *} \\
(.000)\end{array}$ & $\begin{array}{l}-.000^{* * *} \\
(.000)\end{array}$ \\
\hline International Conflict & $\begin{array}{l}-.000 \\
(.000)\end{array}$ & $\begin{array}{l}-.000 \\
(.000)\end{array}$ & $\begin{array}{l}-.000^{\wedge} \\
(.000)\end{array}$ & $\begin{array}{l}-.000 \\
(.000)\end{array}$ & $\begin{array}{l}-.000^{\wedge} \\
(.000)\end{array}$ & $\begin{array}{l}-.000 \\
(.000)\end{array}$ & $\begin{array}{l}-.000 \\
(.000)\end{array}$ & $\begin{array}{l}-.000^{\wedge} \\
(.000)\end{array}$ \\
\hline Lagged DV & $\begin{array}{l}2.405^{* * *} \\
(.054)\end{array}$ & $2.387^{* * *}$ & $2.416^{* * *}$ & $2.407^{* * *}$ & $2.413^{* * *}$ & $2.408^{* * *}$ & $2.399^{* * * *}$ & $2.381^{* * *}$ \\
\hline Observations & 3320 & 3320 & 3333 & 3333 & 3333 & 3333 & 3333 & 3333 \\
\hline Pseudo- $\mathrm{R}^{2}$ & .6419 & .6437 & 6411 & .6426 & .6418 & .6422 & .6431 & .6455 \\
\hline
\end{tabular}

- ${ }^{\wedge} p<.10,{ }^{*} p<.05,{ }^{* *} p<0.01{ }^{* * *} p<.001$ (two-tailed).

- All explanatory variables are lagged one year.

- The results with the Polity $I V$ combined score were not different from the ones with Polity $I V$ democracy score. The results are available from the author.

bilities. If both interaction terms were statistically significant, an explanatory variable had three different effects according to the previous level of violations.

Table 4 reports the sum of the direct effects and significant interaction effects with $\mathrm{y}_{0}{ }^{*}$ and $\mathrm{y}_{1}{ }^{*}$, To confirm the statistical significance of the sum of the coefficients on each variable, a Wald test was conducted on the hypothesis that the sum of the relevant coefficients (the coefficient on each direct effect and the coefficients on statistically significant interaction effects) was o. As shown in column (1) of Table 3, democracy measured with an 11 point-scale Polity $I V$ democracy score had statistically significant coefficients on direct effect and the two interaction effects at the $90 \%$ confidence level, all of which were relevant. If a country was at the low level of human rights violations in the previous year, the coefficient on the democratic effect on the probability that the country remained at the low level was .067 at the $99.9 \%$ confidence level as shown in column (1) of Table 4. If a country was at the medium level in the previous year, the coefficient on the 
democratic effect on the probability that the country reduced human rights violations in the current year was insignificant and its size was .015. If a country was at the high level in the previous year, the coefficient on the probability of a decrease in violations is -..32 and also insignificant. The trichotomous democracy variable had similar results as shown in column (2). The coefficient on the probability of remaining at the low level of violations is .443 at the $99.9 \%$ confidence level, whereas the coefficient on the probability of a decrease from the medium to the low level was .191 and statistically significant only at the $90 \%$ confidence level. The coefficient on the probability of a decrease from the high to the

Table 3. Markov Regression Results

\begin{tabular}{|c|c|c|c|c|c|c|c|c|}
\hline & \multicolumn{8}{|c|}{ Model } \\
\hline & (1) & (2) & (3) & (4) & (5) & (6) & (7) & (8) \\
\hline \multicolumn{9}{|l|}{ Democracy } \\
\hline $\begin{array}{l}\text { Polity IV Democracy } \\
\text { (11 point scale) }\end{array}$ & $\begin{array}{l}.067^{* * *} \\
(.013)\end{array}$ & & & & & & & \\
\hline Trichotomous & & $.443^{* * *}$ & & & & & & \\
\hline Democracy & & $(.082)$ & & & & & & \\
\hline $\begin{array}{l}\text { Executive Recruitment } \\
\text { (EXREC) }\end{array}$ & & & $\begin{array}{l}.068^{* *} \\
(.020)\end{array}$ & & & $\begin{array}{l}-.642^{* * *} \\
(.169)\end{array}$ & & \\
\hline $\begin{array}{l}\text { Executive Constraints } \\
\text { (EXCONST) }\end{array}$ & & & & $\begin{array}{l}.108^{* * *} \\
(.022)\end{array}$ & & & & \\
\hline $\begin{array}{l}\text { Political Competition } \\
\text { (POLCOMP) }\end{array}$ & & & & & $\begin{array}{l}.068^{* *} \\
(.013)\end{array}$ & & & \\
\hline EXREC & & & & & & $\begin{array}{l}.069^{* * *} \\
(.016)\end{array}$ & & \\
\hline Trichotomous EXCONST & & & & & & & $\begin{array}{l}.328^{* * *} \\
(.062)\end{array}$ & \\
\hline Trichotomous & & & & & & & & $.419^{* * *}$ \\
\hline POLCOMP & & & & & & & & $(.073)$ \\
\hline $\begin{array}{l}\text { GDPpc } \\
\text { (in dollar thousands) }\end{array}$ & $\begin{array}{l}.056^{* * *} \\
(.011)\end{array}$ & $\begin{array}{l}.045^{* * *} \\
(.011)\end{array}$ & $\begin{array}{l}.070^{* * *} \\
(.011)\end{array}$ & $\begin{array}{l}.061^{* * *} \\
(.011)\end{array}$ & $\begin{array}{l}.061^{* * *} \\
(.011)\end{array}$ & $\begin{array}{l}.049^{* * *} \\
(.011)\end{array}$ & $\begin{array}{l}.057^{* * *} \\
(.011)\end{array}$ & $\begin{array}{l}.048^{* * *} \\
(.011)\end{array}$ \\
\hline Population & $\begin{array}{l}-.000^{*} \\
(.000)\end{array}$ & $\begin{array}{l}-.000^{*} \\
(.000)\end{array}$ & $\begin{array}{l}-.000^{*} \\
(.000)\end{array}$ & $\begin{array}{l}-.000^{*} \\
(.000)\end{array}$ & $\begin{array}{l}-.000^{\wedge} \\
(.000)\end{array}$ & $\begin{array}{l}-.000^{*} \\
(.000)\end{array}$ & $\begin{array}{l}-.000^{*} \\
(.000)\end{array}$ & $\begin{array}{l}-.000 \\
(.000)\end{array}$ \\
\hline Civil Conflict & $\begin{array}{l}-.001^{* * *} \\
(.000)\end{array}$ & $\begin{array}{l}-.001^{* * *} \\
(.000)\end{array}$ & $\begin{array}{l}-.001^{* * *} \\
(.000)\end{array}$ & $\begin{array}{l}-.001^{* * *} \\
(.000)\end{array}$ & $\begin{array}{l}-.001^{* * *} \\
(.000)\end{array}$ & $\begin{array}{l}-.001^{* * *} \\
(.000)\end{array}$ & $\begin{array}{l}-.001^{* * *} \\
(.000)\end{array}$ & $\begin{array}{l}-.001^{* * * *} \\
(.000)\end{array}$ \\
\hline International Conflict & $\begin{array}{l}.000 \\
(.000)\end{array}$ & $\begin{array}{l}.000 \\
(.000)\end{array}$ & $\begin{array}{l}.000 \\
(.000)\end{array}$ & $\begin{array}{l}.000 \\
(.000)\end{array}$ & $\begin{array}{l}.000 \\
(.000)\end{array}$ & $\begin{array}{l}.000 \\
(.000)\end{array}$ & $\begin{array}{l}.000 \\
(.000)\end{array}$ & $\begin{array}{l}.000 \\
(.000)\end{array}$ \\
\hline Indicator1(yo) & $\begin{array}{l}-2.142^{* * *} \\
(.130)\end{array}$ & $\begin{array}{l}-2.230^{* * *} \\
(.008)\end{array}$ & $\begin{array}{l}-1.860^{* * *} \\
(.239)\end{array}$ & $\begin{array}{l}-2.088^{* * *} \\
(.178)\end{array}$ & $\begin{array}{l}-2.233^{* * *} \\
(.172)\end{array}$ & $\begin{array}{l}-2.512^{* *} \\
(.918)\end{array}$ & $\begin{array}{l}2.162^{* * *} \\
(.121)\end{array}$ & $\begin{array}{l}-2.246^{\text {**** }} \\
(.119)\end{array}$ \\
\hline Indicator2(y1) & $\begin{array}{l}-2.198^{* * *}- \\
(.098)\end{array}$ & $\begin{array}{l}2.296^{* * *} \\
(.088)\end{array}$ & $\begin{array}{l}-2.089^{* * *} \\
(.165)\end{array}$ & $\begin{array}{l}-2.072^{* * *} \\
(.132)\end{array}$ & $\begin{array}{l}-2.038^{* * *} \\
(.117)\end{array}$ & $\begin{array}{l}-3.060^{* * *} \\
(.522)\end{array}$ & $\begin{array}{l}-2.235^{* * *} \\
(.095)\end{array}$ & $\begin{array}{l}-2.251^{* * *} \\
(.091)\end{array}$ \\
\hline Democracy*Indicator1 & $\begin{array}{l}-.047^{\wedge} \\
(.028)\end{array}$ & $\begin{array}{l}-.537^{*} \\
(.265)\end{array}$ & $\begin{array}{l}-.075^{\wedge} \\
(.041)\end{array}$ & $\begin{array}{l}-.051 \\
(.045)\end{array}$ & $\begin{array}{l}-.003^{* * *} \\
(.029)\end{array}$ & $\begin{array}{l}.208 \\
(.375)\end{array}$ & $\begin{array}{l}-.309^{*} \\
(.145)\end{array}$ & $\begin{array}{l}-.117 \\
(.215)\end{array}$ \\
\hline Democracy*Indicator2 & $\begin{array}{l}-.052^{* *} \\
(.018)\end{array}$ & $\begin{array}{l}-.252^{\wedge} \\
(.139)\end{array}$ & $\begin{array}{l}-.053^{\wedge} \\
(.028)\end{array}$ & $\begin{array}{l}-.081^{* *} \\
(.030)\end{array}$ & $\begin{array}{l}-.073^{* * *} \\
(.018)\end{array}$ & $\begin{array}{l}.430^{\wedge} \\
(.228)\end{array}$ & $\begin{array}{l}-.212^{*} \\
(.085)\end{array}$ & $\begin{array}{l}-.306^{*} \\
(.120)\end{array}$ \\
\hline EXREC $^{2 *}$ Indicator1 & & & & & & $\begin{array}{l}-.027 \\
(.034)\end{array}$ & & \\
\hline EXREC $^{2 *}$ Indicator2 & & & & & & $\begin{array}{l}-.048^{*} \\
(.022)\end{array}$ & & \\
\hline GDPpc ${ }^{*}$ Indicator1 & $\begin{array}{l}-.017 \\
(.037)\end{array}$ & $\begin{array}{l}.002 \\
(.042)\end{array}$ & $\begin{array}{l}-.024 \\
(.036)\end{array}$ & $\begin{array}{l}-.028 \\
(.037)\end{array}$ & $\begin{array}{l}-.035 \\
(.036)\end{array}$ & $\begin{array}{l}-.009 \\
(.037)\end{array}$ & $\begin{array}{l}-.009 \\
(.038)\end{array}$ & $\begin{array}{l}-.055 \\
(.040)\end{array}$ \\
\hline GDPpc*Indicator2 & $\begin{array}{l}-.036 \\
(.022)\end{array}$ & $\begin{array}{l}-.030 \\
(.023)\end{array}$ & $\begin{array}{l}-.047^{*} \\
(.022)\end{array}$ & $\begin{array}{l}-.040^{\wedge} \\
(.022)\end{array}$ & $\begin{array}{l}-.037^{\wedge} \\
(.022)\end{array}$ & $\begin{array}{l}-.041^{\wedge} \\
(.024)\end{array}$ & $\begin{array}{l}-.040^{\wedge} \\
(.022)\end{array}$ & $\begin{array}{c}-.029 \\
(.023)\end{array}$ \\
\hline Population* Indicator1 & $\begin{array}{l}-.000 \\
(.000)\end{array}$ & $\begin{array}{l}-.000 \\
(.000)\end{array}$ & $\begin{array}{l}-.000 \\
(.000)\end{array}$ & $\begin{array}{l}-.000 \\
(.000)\end{array}$ & $\begin{array}{l}-.000 \\
(.000)\end{array}$ & $\begin{array}{l}-.000 \\
(.000)\end{array}$ & $\begin{array}{l}-.000 \\
(.000)\end{array}$ & $\begin{array}{l}-.000 \\
(.000)\end{array}$ \\
\hline
\end{tabular}


- ${ }^{\wedge} p<.10,{ }^{*} p<.05,{ }^{* *} p<0.01{ }^{* * *} p<.001$ (two-tailed).

- All explanatory variables are lagged one year.

- The results with the Polity $I V$ combined score were not different from the ones with Polity $N$ democracy score. The results are available from the author.

Table 4. Summary of Markov Results(Transition to Lower Levels of Violations)

\begin{tabular}{|c|c|c|c|c|c|c|c|c|c|}
\hline \multicolumn{10}{|c|}{ Model } \\
\hline & $\begin{array}{l}\text { Past } \\
\text { Level }\end{array}$ & (1) & (2) & (3) & (4) & (5) & (6) & (7) & (8) \\
\hline \multicolumn{10}{|l|}{ Democracy } \\
\hline \multirow[t]{2}{*}{ Polity IV } & & & & & & & & & \\
\hline & High & -.032 & & & & & & & \\
\hline \multirow{2}{*}{ Democracy } & & & & & & & & & \\
\hline & $\begin{array}{l}\text { Med } \\
\text { Low }\end{array}$ & $\begin{array}{l}.015 \\
.067^{* * * *}\end{array}$ & & & & & & & \\
\hline \multicolumn{10}{|l|}{ Trichotomous } \\
\hline & High & & -.346 & & & & & & \\
\hline \multirow[t]{3}{*}{ Democracy } & & & & & & & & & \\
\hline & Med & & $.191^{\wedge}$ & & & & & & \\
\hline & Low & & $.443^{* * *}$ & & & & & & \\
\hline \multirow[t]{3}{*}{ EXREC } & High & & & -.060 & & & -.212 & & \\
\hline & Med & & & $\begin{array}{l}.015 \\
\end{array}$ & & & 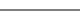 & & \\
\hline & Low & & & $.068^{* * *}$ & & & $-.642^{* * *}$ & & \\
\hline \multirow[t]{4}{*}{ EXCONST } & High & & & & & & & & \\
\hline & & & & & .027 & & & & \\
\hline & Med & & & & $\bar{C}$ & & & & \\
\hline & Low & & & & $.108^{* * *}$ & & & & \\
\hline \multirow[t]{3}{*}{ POLCOMP } & High & & & & & & & & \\
\hline & & & & & & -.005 & & & \\
\hline & $\begin{array}{l}\text { Med } \\
\text { Low }\end{array}$ & & & & & $.068^{* * * *}$ & & & \\
\hline \multirow[t]{4}{*}{ EXREC } & High & & & & & & & & \\
\hline & & & & & & & .022 & & \\
\hline & Med & & & & & & 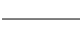 & & \\
\hline & Low & & & & & & $.069^{* * *}$ & & \\
\hline \multicolumn{10}{|l|}{ Trichotomous } \\
\hline \multirow[t]{3}{*}{ EXCONST } & High & & & & & & & -.194 & \\
\hline & Med & & & & & & & $.115^{\wedge}$ & \\
\hline & Low & & & & & & & $.328^{* * *}$ & \\
\hline \multicolumn{10}{|l|}{ Trichotomous } \\
\hline \multirow[t]{2}{*}{ POLCOMP } & High & & & & & & & & .113 \\
\hline & Med & & & & & & & & $419^{* * *}$ \\
\hline \multirow{3}{*}{$\begin{array}{l}\text { GDPpc } \\
\text { (dollar thousands) }\end{array}$} & & & & & & & & & .419 \\
\hline & $\begin{array}{l}\text { High } \\
\text { Med }\end{array}$ & & & .023 & .021 & .024 & .009 & .018 & \\
\hline & Low & $.056^{* * *}$ & $.045^{* * *}$ & $.070^{* * *}$ & $.061^{* * *}$ & $.061^{* * *}$ & $.049^{* * *}$ & $.057^{* * *}$ & $.048^{* * *}$ \\
\hline \multirow[t]{3}{*}{ Population } & High & & & & & & & & \\
\hline & Med & & & & & & & & \\
\hline & Low & $-.000^{*}$ & $-.000^{*}$ & $-.000^{*}$ & $-.000^{*}$ & $-.000^{\wedge}$ & $-.000^{*}$ & $-.000^{*}$ & -.000 \\
\hline \multirow[t]{3}{*}{ Civil Conflict } & High & & & & & & & & \\
\hline & & $-.000^{* *}$ & $-.000^{* *}$ & $-.000^{* *}$ & $-.000^{* *}$ & $-.000^{* *}$ & $-.000^{* * *}$ & $-.000^{* *}$ & $-.000^{* *}$ \\
\hline & $\begin{array}{l}\text { Med } \\
\text { Low }\end{array}$ & $-.001^{* * *}$ & $-.001^{* *}$ & $-.001^{* * *}$ & $-.001^{* * * *}$ & $-.001^{* * * *}$ & $-.001^{* * *}$ & $-.001^{* * *}$ & $-.001^{* * *}$ \\
\hline \multirow{4}{*}{$\begin{array}{l}\text { International } \\
\text { Conflict }\end{array}$} & & & & & & & & & \\
\hline & High & & & & & & & & \\
\hline & Med & & & & & & & & \\
\hline & Low & .000 & .000 & .000 & .000 & .000 & .000 & .000 & .000 \\
\hline
\end{tabular}

$-{ }^{*} \mathrm{~A} p<.10,{ }^{*} \mathrm{p}<.05,{ }^{* *} \mathrm{p}<0.01{ }^{* * *} \mathrm{p}<.001$ (two-tailed).

- The civil conflict variable was removed to avoid the problem of overdetermined observations. 
medium level was -.346 and statistically insignificant. The model with the trichotomous democracy measure had an increased R-squared value from .6486 to .6495 and the impact of democracy moving from the lowest level to the highest level was .886 compared to .67 in the model with the 11point-scale democracy measure. The threshold model seemed to improve predictive as well as explanatory power to some extent.

The models with three elements of institutional democracy measures-executive recruitment, executive constraints, and political competition-yielded identical results to the models with combined democracy measures. As shown in column (3), (4), and (5), all three elements had a strong and statistically significant coefficient on the probability of remaining at the low level of violations but an insignificant coefficient on the probability of a decrease from the medium to the low or the high to the medium levels of violations at the $90 \%$ confidence level. In order to detect a non-linear effect, the square of the executive recruitment variable was added in the model in column (6), and the trichotomous measure of the executive constraints or the political competition variable was used instead of the combined democracy score in column (7) and (8). These non-linear models provide more accurate predictions and suggest a non-linear relationship between democratic elements and human rights violations; however, there is no difference between linear models and non-linear models in the sense that democratic elements show a preventing effect but do not show a decreasing effect. The only exception found was that the executive constraints variable had a statistically significant effect on the probability of a decrease from the medium to the low level at a 90\% confidence level. In the model with the executive recruitment variable and its square, as shown in column (6), both a preventing effect and a decreasing effect showed a quadratic relationship and the two curves of both effects had an inflection point between 4.5 and 5 , which implies that the worst level of violations occurred around this point of the executive recruitment variable. The coefficients of the executive recruitment variable and its square were on a preventing effect and were strong and statistically significant, but those on a decreasing effect were weaker and insignificant. The predictive and explanatory powers of non-linear models were enhanced to some extent. In sum, democracy had a significant and substantially large effect on preventing further violations of human rights but it was not certain that democracy had a significant effect on reducing human rights violations.

The effects of control variables were coherent across the models. Increases in GDP per capita helped governments reduce human rights violations no matter what the starting point was. Population size increased human rights violations regardless of the previous year's condition. The statistical significance of the pop- 
ulation variable varied across the models. Civil conflict also increased human rights violations regardless of past violations, but the effect was greater on governments with a low level of violations in the previous year than on governments with a high level of violations. International conflict had no statistically significant effect on human rights violations.

The coefficients of variables on the probabilities of remaining at a high level of violations and of increases in violations were obtained from the same estimation of the equation presented above. The probability of a movement from the low to the medium level had the same size, but the opposite sign, of the coefficient on the probability of remaining at the low level. The coefficients on the probability of an increase in violations and on the probability of a decrease at the medium level have the same size but the opposite sign. The coefficient on the probability of remaining at the high level has the same size but the opposite sign of the coefficient on the probability of a decrease from the high to the medium level. For instance, the coefficient of the 11 point-scale democracy measure on the probability of remaining at the high level is .032; the coefficient on the probability of an increase from the medium to the high level is -.015; the coefficient on the probability of an increase from the low to the medium level is -.067. In sum, governments were more likely to fall from the low to the medium level of violations as they became less democratic. However, democracy did not have much to do with remaining at, nor changing from, the high level of human rights violations.

Next, I proceeded to analyze the results from the models with an additional variable. I ran five models with the 11 point-scale democracy score and five additional variables. Due to the problem of multicollinearity among those additional variables, I added one other variable to the model. The main reason for the analysis with additional variables was not only to add more controls for the robustness checks of the findings but also to show how other variables worked in a different way than democracy. Table 5 displays the sum of the direct effects and statistically significant interaction effects. The coefficients of democracy and control variables were almost unaffected by the introduction of each of the additional variables. In column (1) and (2) of Table 5, the effects of state capacity variables were estimated. Tax revenue per GDP as a capacity to control territory had no significant effect on a decrease to lower levels of violations, nor on remaining at the low level. Corruption as a measure of the capacity to control state agents was associated with a decrease in human rights violations no matter how severe the past year ${ }^{\circ} Ø s$ violations were. The civil war variable was removed from the model with the corruption variable because many observations were completely determined. Trade per GDP as a measure of the openness of the economy, and the number of NGOs with international linkages, had a positive effect on countries remaining at 
Table 5. Summary of Markov Results(Transition to Lower Levels of Violations)

\begin{tabular}{|c|c|c|c|c|c|c|}
\hline & \multicolumn{6}{|c|}{ Model } \\
\hline & Past Level & (1) & $(2)^{* * *}$ & (3) & (4) & (5) \\
\hline \multirow[t]{4}{*}{ Polity IV Democracy } & High & -.043 & \multirow{3}{*}{.005} & -.040 & \multirow{3}{*}{.008} & -.036 \\
\hline & & & & & & \\
\hline & Med & .004 & & .016 & & .018 \\
\hline & Low & $.070^{* * *}$ & $.056^{* *}$ & $.070^{* * *}$ & $.061^{* * *}$ & $.065^{* * *}$ \\
\hline \multirow[t]{3}{*}{ Trichotomous Democracy } & High & & & & & \\
\hline & Med & & & & & \\
\hline & Low & & & & & \\
\hline \multirow[t]{3}{*}{ GDPpc(dollar thousands) } & High & & & .011 & -.030 & \\
\hline & Med & & & & & \\
\hline & Low & $.045^{* * *}$ & $.043^{* *}$ & $.051^{* * *}$ & $.064^{* * *}$ & $.055^{* * *}$ \\
\hline \multirow[t]{3}{*}{ Population } & High & & & & & \\
\hline & Med & & & & & \\
\hline & Low & $-.000^{*}$ & $-.000^{*}$ & $-.000^{\wedge}$ & -.000 & $-.000^{*}$ \\
\hline \multirow[t]{3}{*}{ Civil Conflict } & High & & & $-.000^{* *}$ & $-.000^{* *}$ & $-.000^{* * *}$ \\
\hline & Med & & & & & \\
\hline & Low & $-.000^{\wedge}$ & & $-.001^{* * *}$ & $-.001^{* *}$ & $-.001^{* * *}$ \\
\hline \multirow[t]{3}{*}{ International Conflict } & High & & & & & \\
\hline & Med & & & & & \\
\hline & Low & .000 & .000 & .000 & .000 & .000 \\
\hline \multirow[t]{3}{*}{ Tax Revenue/GDP } & High & & & & & \\
\hline & Med & & & & & \\
\hline & Low & .868 & & & & \\
\hline \multirow[t]{3}{*}{ Corruption } & High & & & & & \\
\hline & Med & & & & & \\
\hline & Low & & $.152^{*}$ & & & \\
\hline \multirow[t]{3}{*}{ Trade/GDP } & High & & & $.973^{* * *}$ & & \\
\hline & Med & & & $\overline{.226^{\wedge}}$ & & \\
\hline & Low & & & & & \\
\hline \multirow[t]{3}{*}{ NGOs } & High & & & & $.009^{* * * *}$ & \\
\hline & Med & & & & $\overline{.001^{\wedge}}$ & \\
\hline & Low & & & & & \\
\hline \multirow[t]{3}{*}{ IGO Partners } & High & & & & & \\
\hline & Med & & & & & \\
\hline & Low & & & & & $-.389^{*}$ \\
\hline
\end{tabular}

$-{ }^{\wedge} \mathrm{p}<.10,{ }^{*} \mathrm{p}<.05,{ }^{* *} \mathrm{p}<0.01{ }^{* * *} \mathrm{p}<.001$ (two-tailed).

- The civil conflict variable was removed to avoid the problem of overdetermined observations. 
the low level and decreasing from the medium to low level at a 90\% confidence level, but there was a stronger and more significant positive effect on decreasing from the high to the medium level. The results suggest that trade and participation in international NGOs can help countries with severe human rights abuses reduce their violations of human rights. The international organization effects measured using the human rights violations of IGO partners were strong and statistically significant. The human rights practices of IGO partners reduced the human rights violations of countries regardless of past violations.

\section{CONCLUSION}

Does democracy reduce human rights violations? This article asks this seemingly outdated question. With nuanced explanations and sophisticated empirical models, the existing literature concludes that only the strongest democracies reduce human rights violations. Yet, the evidence produced out of static models could be misleading. Numerous cases suggest that countries made major human rights improvements when they did not have fully developed democratic institutions but only a modest degree of accountability or none at all, while some democracies have difficulty improving their human rights records. In pursuit of a coherent explanation for major issues in the literature, such as the correlation between democracy and human rights violations, democratic deficits, and human rights progress under incomplete democracy, this article denies the effect of democratic institutions as the prime cause of better human rights protections and focuses on the effects of democratic institutions on sustaining current good human rights practices. This article addresses the point that human rights could not be the sole goal, but one of the many that governments pursue, and human rights policies are carried out in balance with other policies in consideration of the limited resources available to government leaders. When this point is considered, the whole picture changes completely. Democratic leaders struggle to ensure re-election by meeting the public's demands on various policy goals while simultaneously ensuring the loyalty of government agencies through budgetary allocations. It would be safer for democratic leaders not to make big changes and keep to the status quo, given the limited resources at their disposal. Within a given availability of resources, democratic leaders pursue a portfolio of policies that maximize the probability of being reelected. Human rights reforms may not be at the top of the list. Thus, democratic accountability and checks and balances do not decrease human rights violations but merely prevent further violations.

This article utilized Markov transition models to overcome the problems with other methods for measuring causal inferences, as well as to detect the differences 
between upward and downward movements of human rights violations under democratic and non-democratic political systems. The Markov regression results showed that the likelihood of transition from a higher to lower level of human rights violations was not significantly different across regime types, but the likelihood of remaining at lower levels was greater under democratic political systems than those that were not democratic. The findings provide strong support for the exogenous argument: human rights practices can be ameliorated under any type of regime, but they are less likely to deteriorate in democracies. A decrease in human rights violations was found to be associated with factors other than democracy, such as economic development, state capacity, civil society, and pressure from other countries.

These findings suggest that there is still a lot to learn about this topic. Revealing a complex picture of upward and downward movements of human rights violations and regime characteristics, this study showed that the mechanisms of democracy did not work as previous studies had expected. Democracy may bring more attention to human rights issues but it does not make such efforts successful without changes in domestic power configurations and preferences that usually follow large-scale political upheavals or international pressure. The findings of this article are supportive of the exogenous explanation of human rights improvements and suggest that future work will benefit from exploring democratic institutions as mechanisms for preventing human rights violations more than as an independent cause for behavioral changes. It may be futile to isolate the effect of democracy from socio-economic conditions or international factors as an origin of change since it turns out to be hard to make a clear distinction, and so it will be fruitful to explore how domestic institutions respond to new exogenous changes in power configurations, preferences, and international factors, and move towards a new status quo.

This change of focus will also shed some light on the debate on the multi-dimensionality of democracies. As some scholars suggest (Bueno De Mesquita et al. 2005; Cingranelli and Filippov 2010; Conrad and Moore 2010; Davenport and Armstrong 2004), certain democratic institutions could be more related to decreases in human rights violations. The distinction between the decreasing and the preventing effects of democracy should be considered when one assesses the effect of various democratic institutions. Different elements of democracy may not help decrease human rights violations but may be helpful in preventing those violations. For instance, the effects of a veto system may be limited when it comes to human rights improvements but no less effective than other elements in keeping current human rights practices. Future work should assess which elements of democracy are more effective in maintaining good human rights practices, as well 
as creating those practices if they do, in fact, help to maintain them. The study of multi-dimensional mechanisms of the democracy effects on human rights should be expanded by loosening the assumption of a universal preference for better human rights protections. Future attention needs to be paid to the reasons why domestic constituencies choose existing repressive governments or prospective illiberal leaders. This happens not only in competitive autocracies but also in liberal democracies. During the last few decades, many countries, including Hungary, Poland, and South Korea, experienced liberal democratic setbacks even though their democratic institutions may have prevented more severe human rights violations from occurring. It is apparent that those countries do not put forth as much effort as they used to previously, and domestic constituencies have chosen repressive governments, or at least endorsed them, ex post facto. Why and how could this have happened? It would be useful to examine to what extent human rights issues affected voter choices and determined the results of elections in comparison with other policy issues. It would also be useful to look into how human rights issues are linked with other policies, including foreign policies, and how they influence people's preferences and produce electoral results, and how domestic constituencies adhere to or abandon human rights issues as other policies take precedence.

\section{REFERENCES}

Ahnen, Ronald E. 2007. "The Politics of Police Violence in Democratic Brazil." Latin American Politics and Society 49 (1), 141-164.

Amnesty International. 2015. Amnesty International Report 2014/15: The State of the World's Human Rights. London: Amnesty International. Accessed at https://www.amnesty.org/en/documents/pol1o/o001/2015/en/ (July 20, 2016).

Armstrong II, David A.2009. 'Democracy and State Repression: What We Don' t Know Can Kill Us." Ph.D Dissertation, University of Maryland, College Park.

Brysk, Alison. 1994. The Politics of Human Rights in Argentina: Protest, Change, and Democratization. Stanford, CA: Stanford University Press.

Bueno de Mesquita, Bruce, George W. Downs, Alastair Smith and Feryal Marie Cherif. 2005. "Thinking Inside the Box: A Closer Look at Democracy and Human Rights." International Studies Quarterly 49(3), 439-458.

Call, Charles T. 2002. "War Transitions and the New Civilian Security in Latin America." Comparative Politics 35(1), 1-20. 
Cao, Xun, Brian Greenhill and Aseem Prakash. 2013. "Where is the Tipping Point? Bilateral Trade and the Diffusion of Human Rights." British Journal of Political Science 43(1), 133-156.

Cardenas, Sonia. 2007. Conflict and Compliance: State Responses to International Human Rights Pressure. Philadelphia, PA: University of Pennsylvania Press.

Carey, Sabine C. 2006. "The Dynamic Relationship between Protest and Repression." Political Research Quarterly 59(1), 1-11.

Cingranelli, David L. and David L. Richards. 1999. "Respect for Human Rights after the End of the Cold War." Journal of Peace Research 36(5), 511-534.

Cingranelli, David L. and Mikhail Filippov. 2010. "Electoral Rules and Incentives to Protect Human Rights." Journal of Politics 72(1), 243-257.

Conrad, Courtenay Ryals and Will H. Moore. 2010. "What Stops the Torture?" American Journal of Political Science 54(2), 459-476.

Davenport, Christian. 1996. "The Weight of the Past: Exploring Lagged Determinants of Political Repression." Political Research Quarterly 49(2), 377-403.

1999. "Human Rights and the Democratic Proposition." Journal of Conflict Resolution 43(1), 92-116.

. 2004. "The Promise of Democratic Pacification: An Empirical Assessment." International Studies Quarterly 48(3), 539-560.

2007. State Repression and the Domestic Democratic Peace. Cambridge: Cambridge University Press.

Davenport, Christian and David A. Armstrong. 2004. "Democracy and the Violation of Human Rights: A Statistical Analysis from 1976 to 1996." American Journal of Political Science 48(3), 538-554.

Davis, Darren W. and Brian D. Silver. 2004. "Civil Liberties vs. Security: Public Opinion in the Context of the Terrorist Attacks on America." American Journal of Political Science 48(1), 28-46.

Diamond, Larry. 1996. "Democracy in Latin America: Degrees, Illusions, and Directions for Consolidation." In Tom Farer ed., Beyond Sovereignty: Collectively Defending Democracy in the Americas. Baltimore: Johns Hopkins University Press, 52-104. 2008. The Spirit of Democracy: The Struggle to Build Free Societies Throughout the World. New York: Henry Holt Books.

Domber, Gregory F. 2013. "Poland: International Pressure for a Negotiated Transition, 1981-1989." In Kathryn Stoner and Michael McFaul eds., Transitions to Democracy: A Comparative Perspective. Baltimore: Johns Hopkins University Press, 62-90. 
Drake, Paul W. 1998. "The International Causes of Democratization, 1974-1990." In Paul W. Drake and Mathew D. McCubbins eds., The Origins of Liberty: Political and Economic Liberalization in the Modern World. Princeton, NJ: Princeton University Press, 70-91.

Englehart, Neil A. 2009. "State Capacity, State Failure, and Human Rights." Journal of Peace Research 46(2), 163-180.

Epstein, David L., Robert Bates, Jack Goldstone, Ida Kristensen and Sharyn O' Halloran. 2006. "Democratic Transition." American Journal of Political Science 50(3), 551-569.

Fein, Helen. 1995. "More Murder in the Middle: Life Integrity Violations and Democracy in the World, 1987." Human Rights Quarterly 17(1), 170-191. Forsythe, David P. 2012. Human Rights in International Relations. Cambridge: Cambridge University Press.

Fukuyama, Francis. 2004. State-Building: Governance and World Order in the $21^{\text {st }}$ Century. Ithaca, NY: Cornell University Press.

Hafner-Burton, Emilie M. 2013. Making Human Rights a Reality. Princeton, NJ: Princeton University Press.

Hafner-Burton, Emilie M. and James Ron. 2009. "Seeing Double: Human Rights Impact Through Qualitative and Quantitative Eyes." World Politics 61(2), 360-401.

Holms, Stephen. 1999. "Constitutionalism, Democracy, and State Decay." In Harold Hongju Koh and Ronald Slye eds., Deliberative Democracy and Human Rights. New Haven, CT: Yale University Press, 116-135.

Hsiao, Hsin-Huang Michael and Hagen Koo. 1997. "The Middle Classes and Democratization." In Larry Diamond, Marc F. Plattner, Yun-han Chu and Hung-mao Tien eds., Consolidating the Third Wave Democracies. Volume 1: Themes and Perspectives. Baltimore: Johns Hopkins University Press, 312-333.

Htun, Mala. 2003. Sex and the State. Cambridge: Cambridge University Press.

Jaung, Hoon. 2009. "The Two Tales of the Korean Presidency: Imperial but Imperiled Presidency." In Jongryn Mo and David W. Brady eds., The Rule of Law in South Korea. Stanford, CA: Hoover Institution Press, 61-82.

Kaplan, Robert D. 2002. The Coming Anarchy: Shattering the Dreams of the Post Cold War. New York, NY: Random House.

Keith, Linda Camp and Steven C. Poe. 2004. "Are Constitutional State of Emergency Clauses Effective?" Human Rights Quarterly 26(4), 1071-1097.

Lacina, Bethany and Nils Petter Gleditsch. 2005. "Monitoring Trends in Global Combat: A New Dataset of Battle Deaths." European Journal of Population 21(2),145-166. 
Levitsky, Steven and Lucan Way. 2005. "International Linkage and Democratization." Journal of Democracy 16(3), 20-34.

Lijphart, Arend. 1977. Democracy in Pluralistic Society: A Comparative Exploration. New Haven, CT: Yale University Press.

Lipset, Seymour Martin. 1959. "Some Social Requisites of Democracy." American Political Science Review 53(1), 69-105.

Mann, Michael. 2005. The Dark Side of Democracy: Explaining Ethnic Cleansing. Cambridge: Cambridge University Press.

Mansfield, Edward D. and Jack L. Snyder. 2005. Electing to Fight: Why Emerging Democracies Go to War. Cambridge, MA: MIT Press.

Meernik, James. 1996. "United States Military Intervention and the Promotion of Democracy." Journal of Peace Research 33(4), 391-402.

Mitchell, Neil J. and James M. McCormick. 1988. "Economic and Political Explanations of Human Rights Violations." World Politics 40, 476-498.

Mousseau, Michael and Demet Yalcin Mousseau. 2008. "The Contracting Roots of Human Rights." Journal of Peace Research 45(3), 327-344.

Murdie, Amanda and David R. Davis. 2010. "Problematic Potential: The Human Rights Consequences of Peacekeeping Interventions in Civil Wars." Human Rights Quarterly 32(1), 49-72.

Poe, Steven, C. and C. Neal Tate. 1994. "Repression of Personal Integrity Rights in the 1980's: A Global Analysis." American Political Science Review 88(4), 853-872.

Poe, Steven, C., C. Neal Tate and Linda Camp Keith. 1999. "Repression of the Human Rights to Personal Integrity Revisited: A Global Cross-National Study Coveringthe Years 1976-1993." International Studies Quarterly 43(2), 291-313.

Poe, Steven, C., C. Neal Tate, Linda Camp Keith and Drew Lanier. 200o. "Domestic Threats: The Abuse of Personal Integrity." In Christian Davenport ed., Path to State Repression. Lanham, MD: Rowman and Littlefield, 27-70.

Przeworski, Adam and Fernando Limongi. 1997. "Modernization: Theories and Facts." World Politics 49(2), 155-183.

Przeworski, Adam, Michael E. Alvarez, Jose Antonio Cheibub and Fernando Limongi. 2000. Democracy and Development: Political Institutions and Well-Being in the World, 1950-1990. Cambridge: Cambridge University Press.

Risse, Thomas and Stephen C. Ropp. 1999. "International Human Rights Norms and Domestic Change: Conclusion." In Thomas Risse, Stephen C. Ropp and Kathryn Sikkink eds., The Power of Human Rights: International Norms and Domestic Change. Cambridge: Cambridge University Press, 
234-278.

Sato, Hajime. 2002. "Abolition of Leprosy Isolation Policy in Japan: Policy Termination Through Leadership." Policy Studies Journal 30(1), $29-46$. Simmons, Beth A. 2009. Mobilizing for Human Rights: International Law in Domestic Politics. Cambridge: Cambridge University Press.

Sobek, David, M. Rodwan Abouharb and Christopher G. Ingram. 2006. "The Human Rights Peace: How the Respect for Human Rights at Home Leads to Peace Abroad." Journal of Politics 68(3), 519-529.

Tsebelis, George. 2002. Veto Players: How Political Institutions Work. Princeton, NJ: Princeton University Press.

Walker, Scott and Frederic S. Pearson. 2007. "Should We Really 'Force Them to Be Free?' An Empirical Examination of Peceny's Liberalizing Intervention Thesis." Conflict Management and Peace Science 24(1), 37-53. Zakaria, Fareed. 2003. The Future of Freedom: Illiberal Democracy at Home and Abroad. New York, NY: W. W. Norton \& Company. 